\title{
Practices of Public Relations Agencies in the Sultanate of Oman in light of the Excellence Theory and Creativity Concept
}

\author{
"Dr. Iman Zahra \\ "Karima Al Balushi
}

\section{Introduction}

Public relations is considered one of the oldest media and managerial functions in some Arab countries and the whole world, since the real practice of $P R$ in the Arab region could be traced back to the sixties of the twentieth century (Youssef and Zahra, 2011: 125). Public Relations in the Sultanate of Oman, though, is a nascent domain that mostly coincided in theory and practice with the renaissance era in 1970 when Sultan Qaboos Bin Said took over (Zahra, 2014). Nevertheless, researchers traced some PR- like activities that took place in Oman before the renaissance era, mostly to serve the political objectives of the government at the time. "Al Barza council" as an example was a form of gathering joining rulers from a certain area aiming at communicating the voice of the government, explaining its policies and improving its image among the local population. Another local council "Al Sabla" was also formed for a similar but merely local reason targeting mostly members of certain tribe or clan (AlHinai, 2012). Shortly before the renaissance, and specifically in 1968, the modern PR started formulating, when the Petroleum Development Oman (PDO) Company issued the newsletter "Our Company News" as a journalism and PR activity to publicize the company, employees and activities news (Ismail, 2017: 72-73).

PR in Oman witnessed a remarkable development that accompanied

*Lecturer, Public Relations and Advertising Department, Faculty of Mass Communication, Cairo University

*Mass Communication Department, College of Arts and Social Sciences, Sultan Qaboos University, Muscat, Oman 
the development witnessed by the Sultanate since the dawn of the renaissance. Ikram (2015: 132) asserted that PR is fast growing to maturity and witnessing a revolutionary change; for the profession is recognized as an important instrument to realize the market goals of the organizations; especially since the global economic recession in the recent past has increased the prospects of PR.

Concerning PR research, previous studies found out that PR relations research is considered one of the oldest media research trends in communication studies in most Arab countries, since some PR studies are more than six decades old (Youssef and Zahra, 2011). As for Oman, PR scientific research have started extensively with the inauguration of the local postgraduate programs a little more than a decade ago; when the master program in Communication in Sultan Qaboos University the leading university in the Sultanate was launched in 2005. However, practicing PR in governmental and private institutions much preceded submitting the phenomenon into regulated scientific investigation as previously mentioned (Al-Hinai, 2012; Zahra, 2015).

As the business sector in the Sultanate flourished, complexity of the commercial based companies contributed to concentrating on certain forms of PR especially PR agencies and consultancies (Zahra, 2015). Lages and Simkin (2003: 304) recited broad definitions of a consultancy as: "a process in which a consultant provides a service to a client for the purpose of meeting the client's needs". Public relations agencies - as contrasted to management consultancies, advertising and corporate design agencies are described as: "agencies which offer services predominantly in corporate image-building to various external constituencies". Wynee (2013) compared between PR agencies and advertising agencies in the sense that: "PR agencies, as opposed to advertising agencies, promote companies or individuals via editorial coverage. This is known as "earned" or "free" media stories appearing on websites, newspapers, magazines and TV 
programs - as compared to "paid media" or advertisements". PR agencies and advertising agencies share the same goals: "promoting clients and making them seem as successful, honest, important, exciting or relevant as possible".

The general functions of a public relations agency include some or all of the following tactics:

- Write and distribute press releases.

- Speech writing.

- Write pitches about a firm and send them directly to journalists.

- Create and execute special events designed for public outreach and media relations.

- Conduct market research on the firm or the firm's messaging.

- Expansion of business contacts via personal networking or attendance and sponsoring at events.

- Copy writing and blogging for the web (internal or external sites).

- Crisis public relations strategies.

- Social media promotions and responses to negative opinions online.

Assuming that PR agencies provide creative solutions for clients, creativity in public relations must be meticulously defined and specified. Green (2010: 4) argued that creativity is much easier to detect than to define. In general, creativity definitions fall into four categories:

- Creativity as an individual talent.

- Creativity as a process.

- Creativity as a product

- Creativity as recognition by others 
Green (2010: 5) defines creativity for PR as: "the ability to create something new by bringing together two or more different elements in a new context, in order to provide added value to a task." Accepting the previous definition, the researcher tends to believe that PR agencies are considered to be the creative factories of PR, managing companies' images and managerial aspects differently, thus enhancing the creativity of the account in hand.

In light of the importance of creativity of PR agencies and due to the need to build the concept on a solid theory, this study intends to characterize the practices of public relations agencies in the Sultanate of Oman of utilizing the Excellence Theory of public relations while tackling the creativity aspects practiced by those agencies.

\section{The Excellence Theory of Public Relations}

It is well known in the accumulative PR literature that James Grunig and Todd Hunt (1984) were the first two researchers to suggest four traditional methods of practicing public relations, widely known as PR models. The researchers derived the four models from two major communication variables: direction (one vs two way) and purposebalance of effect (asymmetrical vs symmetrical). These four models namely Press Agentry Model, Public Information Model, Two-way Asymmetrical model and Two- way Symmetrical model represent values, objectives and sets of behavior adopted by different organizations in executing PR functions nowadays (see: Grunig and Hunt, 1984: 13-46; Grunig and Grunig, 1992: 287-289). In 1992, Grunig and Grunig (1992: 307-308) asserted on the eligibility of the two-way symmetrical model to be the excellent characteristic of the PR programs adopting it, thus increasing the effectiveness of the organizations.

"The excellence project defines public relations as the "management of communication between an organization and its publics". This definition equals public relations and communication management. 
Public relations and communication management describe the overall planning, execution, and evaluation of an organization's communication with both external and internal publics- groups that affect the ability of an organization to meet its goals" (Grunig et al., 2008: 4).

\section{Characteristics of excellent public relations}

Zerfass et al. (2008: 335-336) stated that the characteristics of an excellent public relations function could be placed into four categories, each containing several characteristics as well.

\section{Empowerment of the Public Relations Function}

For public relations to contribute to organizational effectiveness, the organization must empower public relations as a critical management function. Empowerment of the public relations function covers four characteristics of excellent public relations, namely:

The senior public relations executive is involved with the strategic management processes of the organization, and communication programs are developed for strategic publics identified as a part of this process.

Communication programs organized by excellent departments to communicate with strategic publics also are managed strategically. Programs are based on formative research and have concrete and measurable objectives.

The senior public relations executive is a member of the dominant coalition of the organization or has a direct reporting relationship to senior managers who are part of the dominant coalition.

Diversity is embodied in all public relations roles. The principle of requisite variety suggests that organizations need as much diversity inside as in their environment if they are to interact successfully with all strategic elements of their environment. 


\section{Public Relations Roles:}

Botan \& Hazleton (2009: 36) mentioned that the excellence theory examined three theoretical prepositions related to roles:

The public relations unit is headed by a manager rather than a technician who conceptualizes and directs public relations programs.

The senior public relations executive or others in the public relations unit must have the knowledge needed for the manager role or the communication function will not have the potential to become a managerial function.

Both men and women must have equal opportunity to occupy the managerial role in an excellence department.

\section{Organization of the Communication Function and its Relationship to other Management Functions}

Zerfass et al. (2008: 337) dictated two crucial characteristics related to the organization of the PR function:

An excellent public relations function integrates all public relations programs into a single department or provides a mechanism for coordinating programs managed by different departments.

Even though the public relations function is integrated in an excellent organization, the function should not be placed in another department whose primary responsibility is a management function other than communication.

\section{Models of Public Relations}

Botan \& Hazleton (2009: 40-41) specified three prepositions based on the symmetrical model:

$\square$ The public relations department and the dominant coalition share the worldview that the communication department should reflect the two-way symmetrical model. 
$\square$ Communication programs developed for specific publics are based on the two-way symmetrical model.

The senior public relations executive or others in the public relations unit must have the knowledge needed for the two-way symmetrical model or the communication function will not have the potential to practice that excellent model.

\section{Presuppositions of symmetrical worldviews:}

The previous review hypothesizes that excellent PR is the effective public relations based on symmetrical worldviews. The symmetrical model has the following characteristics (Deatherage \& Hazleton, 2009: 58-59):

Interdependence: Organizations cannot isolate themselves from their environment, publics and other organizations.

Open system: The organization is open to interpenetrating systems and freely exchanges information with those systems.

Moving equilibrium: Organizations as systems strive toward an equilibrium with other systems.

Equity: People should be given equal opportunity and be respected as fellow humans.

Autonomy: People are more innovative, constructive, and selffulfilled when they have the autonomy to influence their own behavior.

Innovation: New ideas and flexible thinking, rather than tradition and efficiency should be stressed.

Decentralization of management: Management should be collective as decentralization increases autonomy, employee satisfaction, and innovation.

Responsibility: People and organizations must be concerned with the 
consequences of their behaviors on others.

Conflict resolution: Conflict should be resolved through negotiation, communication and compromise.

Interest group liberalism: This liberalism views the political system as a mechanism for open negotiation among interest or issue groups.

The excellence theory has been submitted to extensive hypotheses testing since the last decade of the past century. Almost all studies proved that the excellence principles can be applied to PR practice in different cultural contexts (Lim et al., 2005). Lots of PR studies in most Arab countries placed every aspect of the new theory - at the time - under scrutiny starting from the first decade of the new century (see for example: Zahra, 2002; Taha: 2003; El- Ghazali, 2006; Hussein, 2009). As PR specialized - theory based- studies in Oman are still infantile, it was not until 2015 that the excellence theory had been subjected to proper studies (see for example: Al Siyabi, 2015). Results though, were inconclusive as to whether PR practices in Oman can follow the excellence principles or not. This indecisiveness poses the need for more research scrutinizing practicing most aspects of the renowned theory in different entities; including PR agencies that haven't been subjected to direct research in Oman.

\section{Creativity of PR Agencies}

Sefertzi (2000: 2) defines creativity in general as "the generation of new ideas or the recombination of known elements into something new, providing valuable solutions to a problem. It also involves motivation and emotion". White (2000: 84) defines creativity as "the production of novel and useful ideas in any domain". Innovation, though, is the successful implementation of creative ideas within an organization. Creativity is a product of persons, processes and products. Components of creativity include expertise, creative thinking and task motivation .Gomez (2007: 31) pointed out that 
creativity is viewed differently in different domains and disciplines, for example; in education, it is called "innovation"; in business "entrepreneurship"; in mathematics, it is sometimes equated with "problem-solving", and in music it is "performance or composition". Creativity as a strategic tool exists as one of the values of the organization. It comes out of planning and strategic thinking and because the organization includes creativity in their business goals, they are able through PR, advertising, merchandising or design to behaviorally demonstrate their creativity (Green, 2010: 119). These are influenced by organizational factors, such as the organizational motivation to innovate, resources and management practices (White, 2000: 84).

In PR, creativity seems to be the management of communication, or problem solving, or company's reputation or products and services development. Public relations is a 'creative industry', along with advertising, the media and the performing arts (Daymon, 2000: 18). According to Palea (2010: 20) creativity in public relations is supposed to "earn trust, to add value, to change the attitude, behavior and beliefs of the company's publics".

There are five important trends in the PR business according to Jakus, \& Croatia (2013: 6-7) that can help public relations practitioners to have an effective creative process. These trends are:

1. Storytelling: in order to be an effective in public relations, you have to be a good storyteller, and to be a good storyteller don't tell lies, don't tell fancy stories, don't tell what you don't mean, don't say what others want to hear. That means you have to tell the truth and definitely you have to tell a life not a fairytale. Good storytellers are people who think and speak directly, they do not think twice.

2. Think in pictures: visual communication is necessary in the work of public relations. The videography, photography, and 
design art can make the work of public relations more creative.

3. More people can make more things directly: involving in social media and industry discussion groups is very important in order to observe how conversations work, how ideas flow, and to evaluate discussions and issues.

4. See local as the new global: It is important for PR practitioners to have audiences, especially local audiences that will help them during time of requirement or crisis.

5. Adaptation: public relations practitioners have to adapt themselves to the change, means they have to predict the changes that will happen and adapt themselves for this change.

There is a list of important components in PR providing an extensive view of the domain, which are: consulting, media relations, publicity, research, relations with the employees/ members, relations with the community, issue management, governmental affairs, public affairs, fund raising, special events, marketing communication (Palea, 2010: 19). As a tactical tool, Green (2010: 121-131) could identity 24 creativity practices that could be applied to any aspect of public relations as: creativity through identifying allies, corporate hospitality, media use, taking advantage of a negative opportunity, lobbying, award winning, packaging, use of spokesmen, creating unusual events and sponsorships.

These components are important to develop in creativity work in public relations agencies, firms and consultancies. The consultancy process itself is one that demands creativity. It involves assessment of symptoms, causes and remedies of client problems. The thinking processes at work are divergent, allowing for the generation of ideas, convergent, to focus in on assessment of solutions, and analytical, as issues are formulated, causes found and solutions developed. The entire process can be seen as a creative one that leads to action plans. Consultancies also make extensive use of techniques such as brainstorming. Such techniques are based on research, known facts, 
and a willingness to leave preconceptions behind. (White, 2000: 84).

Contrary to White's account of creative consultancies; Daymon (2000) examined the nature and the dynamics of creativity through which it is fostered or hampered. She attempted to answer two main questions: what is the nature of creativity, and how is it accommodated in public relations consultancies? Primary research consisted of interviews and a focus group with public relations practitioners in small, medium and large global consultancies in London and the regions. Interviews were conducted with ten members of five public relations consultancies based in London and the south of England. Findings suggested that creativity is characterized by three dimensions: unconventionality, autonomy and risk. The manner in which consultancies organize and manage these, determined the extent to which creativity is stimulated or stifled. The styles of management and the forms of organization which accommodate creativity are primarily influenced by size, client expectations, and the individualistic nature of public relations practitioners.

As for the unconventionality dimension, the study stated that much work in public relations consultancies is routine, concerned with implementing strategies, which conform to the accepted practices of each consultancy. Client campaigns differ, but these are activated through standard work practices, such as writing press releases, talking with journalists, managing promotional events, arranging sponsorship deals, advising on industry trends, doing research, and contributing to presentations. Although an element of originality is needed to be effective in these activities, practitioners rely on their expertise and previously successful experiences to inform how they implement campaigns. It is at the stage of devising and designing public relations programs that originality is most clearly expressed (Daymon, 2000: 20).

Thinking that is unconventional emerges because individuals or 
groups have discretion to make their own decisions about how to carry out work processes, what work should consist of, the selection of appropriate roles within teams, or what the outcomes of work should be. A second dimension of creativity, then, is autonomy (Daymon, 2000: 22). As for the risk as a third dimension, the risks for any business involved in creativity concern creativity's unpredictable nature. At the center of public relations practice are subjective judgments and processes that are based on information and ideas; these have indeterminate outcomes because of their intuitive nature. Each time a public relations program is devised, it is in the expectation that audiences will respond favorably and client goals will be fulfilled. There is no guarantee of success, however. First, as in all creative industries, the responses of audiences, the media and markets are often unpredictable. Different situational factors (such as the composition of teams, resources and client relationships) mean that what has worked before is not automatically successful next time (Daymon, 2000: 24).

\section{PR Agencies in the Sultanate of Oman}

Because Public Relations Agency practice in the Arab world as a whole is relatively new, some Arab researchers (Agwa and Youssef, 2005: 85-89) speculated that the reasons behind the late establishment of such agencies; let alone their creativity practices could be summarized in the following:

1- The lack of independent means of communication, which are not under the control of the government at the very least.

2- Lack of awareness of the importance of gaining the support of public opinion, in addition to the importance of conducting research in this regard.

3- Lack of early awareness of the importance of government relations, media relations, relations and industry relations in the political and economic success of different entities. 
4- Confusion between the field of public relations and other areas of communication, which led to the integration of public relations activities under the name of other agencies and firms. This is evident in the adoption of advertising agencies the practice of public relations activities (and this case is evident in Oman as will be mentioned hereafter).

5- Misunderstanding and limiting the work of public relations in different institutions, moreover not keeping pace with the developments of the profession and relying only on the provision of typical services such as reception of guests and clearance of passports, not as a true liaison between the institution and the public.

6- Lack of awareness of the important role of public relations agencies in the promotion of tourism and global trade.

In the case of PR agencies in the Sultanate of Oman; it was pretty obvious from observation, interviews with designated personnel in different agencies and visits to official responsible institutions as the Omani Chamber of Commerce and Ministry of Commerce and Industry that the actual number of PR firms in the Sultanate of Oman is unspecified. Reasons behind this weird phenomenon reside into:

- Confusion between the field of public relations in Oman and other areas of communication, which led to the integration of public relations activities under the name of other agencies and firms specialized in promotion, marketing, advertising and general communication.

- The PR firms are divided into two major types: one specialized in PR as a whole with all its activities and the other is specialized in executing one or more PR activities as organizing events, planning PR campaigns, exhibition establishment, outdoor PR advertising, printing and production 
services, social media services and audio-visual production.

After undergoing various unstructured interviews with consultants in different agencies, it turned out that there are lots of PR agencies and firms based in Oman; whether national or international, specialized in a certain activity or practicing comprehensive PR activities. Some of the most renowned PR firms in Oman are:

- TRACCS

- TALKS

- ADNIC DDB

- Echoes

- Momentum PR

- UMS

- Weber Shandwick

- Zeinna

To further investigate the number and specializations of PR firms in Oman, the researchers resided to the certified Omani SABCO guidebook entitled Media Te version of 2015/2016, where it was stated that 105 PR firms are established in Oman, 97 of those are based in Muscat, Oman's capital. The following table clarifies the number and specializations of Muscat PR firms

Table (1)

\section{Characterization of Muscat-based PR Agencies and firms}

\begin{tabular}{|c|c|c|c|}
\hline & Specialization & $\mathrm{N}$ & $\%$ \\
\hline 1 & Public Relations (Wholesome practice) & 10 & 10.3 \\
\hline 2 & Organizing Events & 21 & 21.6 \\
\hline 3 & Planning PR Campaigns & 26 & 26.8 \\
\hline 4 & Exhibition Establishment & 9 & 9.3 \\
\hline 5 & Outdoor PR Advertising & 7 & 7.2 \\
\hline 6 & Printing and Production Services & 9 & 9.3 \\
\hline 7 & Social Media Services & 9 & 9.3 \\
\hline 8 & Audio-Visual Production & 6 & 6.2 \\
\hline Total & & 97 & 100 \\
\hline
\end{tabular}


All the above categories were presented in the study as will be elaborated on hereafter.

\section{Methodology and literature review}

\section{- Research Problem:}

This study intends to characterize the practices of public relations agencies and firms in the Sultanate of Oman in light of the Excellence Theory of public relations as a preliminary step then detect the creative practices of the firms in hand. The paper focuses on three aspects: the internal organization of the agencies, the services provided for clients and the creativity practices executed by them. The reason behind focusing on Creativity in Omani PR agencies is the same reason that triggered Daymon's study of British PR firms; that is "the need to understand how creativity is accommodated in different PR organizations"; thus solely focusing on public relations consultancies rather than on other entities, that might not have captured the true essence of creativity.

\section{- Research Questions:}

The current research is set to answer one major question namely What are the methods of practicing public relations in public relations agencies and firms in Oman in accordance with the excellence theory of public relations; regarding three facets: the internal organization framework of those agencies, services provided to clients and finally utilizing the creative dimension to provide better clientele services?

Three sub-questions are derived from this major question as follows:

A) Questions concerning the internal regulation framework for public relations agencies and firms in the Sultanate of Oman.

1) What is the description of PR practices in the agencies located in the Sultanate of Oman?

2) What are the characteristics of excellence in the PR practice of 
agencies in the Sultanate of Oman?

B) Questions related to the services provided by public relations agencies and firms in the Sultanate of Oman to clients.

1) What are the services and consultations offered by Omani PR agencies and firms to their clients?

2) To what extent do public relations agencies and firms in the Sultanate of Oman apply the characteristics of excellence in providing their services to clients according to the two-way models governing the profession?

C) What are the creativity practices executed by PR agencies and firms in the Sultanate of Oman to provide a better clientele experience?

\section{- Research Method and Sampling Procedures:}

This study is considered both exploratory and descriptive depending on survey methodology. SABCO guide book (media te: 2015/2016) was used to extract the sample of the study, since it covers public relations agencies and firms in the Sultanate of Oman.

The researchers chose Muscat Governorate, Oman's capital only to execute the study since 97 agencies out of the wholesome population counting for 105 agencies are situated in Muscat; with a rate of $92.4 \%$. The study's preliminary goal was to include all the 97 agencies into it; administering one questionnaire per each agency. After thorough investigation, this inclusive sampling turned out to be an impossible procedure, due to the weak response rate from the 97 agencies via different collection methods: personal visits or emails. Finally, the study was conducted on a convenience sample of 57 PR agencies and firms operating in Muscat Governorate, which represents the sample of the agencies and firms that approved to be included in the study $(58.8 \%)$ of the total study population. The data collection process lasted about two months and ten days between April and June 2016. 
The sample consisted of agencies specialized in a certain service, agencies practicing general PR services, and some even combining PR and Advertising services as shown in the following table.

Table (2)

Characterization of the Study Sample

\begin{tabular}{|c|c|c|c|}
\hline & Specialization of Agency & $\mathrm{N}$ & $\%$ \\
\hline 1 & Public Relations (Wholesome practice) & 8 & 14 \\
\hline 2 & Organizing Events & 13 & 22.8 \\
\hline 3 & Planning PR Campaigns & 18 & 31.6 \\
\hline 4 & Exhibition Establishment & 8 & 14 \\
\hline 5 & Outdoor PR Advertising & 3 & 5.3 \\
\hline 6 & Printing and Production Services & 1 & 1.8 \\
\hline 7 & Social Media Services & 4 & 7 \\
\hline 8 & Audio-Visual Production & 2 & 3.5 \\
\hline Total & & 57 & 100 \\
\hline
\end{tabular}

An Arabic and English version of the same questionnaire were prepared and evaluated as a tool for data collection. The questionnaire was distributed among executives or their representatives in the agencies and firms subject to study administering only one questionnaire per agency. Questions were designed only to be answered by the executive category for the following reasons:

- Agency executives are qualified to give a clear description of the internal organization of the agency.

- Agency executives are qualified to present a clear picture of the services provided by them to clients.

- Agency executives are qualified to describe the creative procedures taken by the entity to serve clients.

The questionnaire dwelled upon three aspects: internal organization framework of those agencies, services offered to clients and finally open ended questions concerning utilizing the creative dimension to provide better clientele services. 


\section{- Literature Review:}

As prior mentioned creativity is one of the least tackled topics when it comes to PR agencies. Daymon (2000) and White (2000) were two of the rare researchers to dwell upon the idea. No previous studies as well tackled Public Relations or even Advertising agencies in Oman; being a nascent communication domain. Generally speaking, studies that dealt with aspects related to PR agencies are massive in number and indirectly related to the current research. Most studies considered managerial aspects as the internationalization of PR agencies (Molleda et al., 2015), or company mergers (Bashir and Fedorova, 2014), or the relationship between upper management and the employees of the agency (Gallicano, 2013), or the return on agency investment (Everling, 2009), or leadership and gender roles (Janus, 2008). Others considered communication and relation aspects, as utilizing communication technology and social media in the agencies services (Traintafillidou and Yannas, 2014) or agencies expertize (Remund, 2011) or the relationship between agencies and clients (Mart and Jackson, 2005). Some studies took the comparative style through setting up comparative criteria between PR agencies from different countries (Fedorova, 2012). Most results, though not related to the current study, valued a close and intimate relationship between the agencies and clients, depending on different aspects as regular meetings, via utilizing all the agencies capabilities to execute proper timely services to their clients.

Studies related to the excellence theory of public relations whether previous or recent, originating from the west or from the east, via using different methodologies; have all resulted in one major finding; that is the two way asymmetrical model tends to be the ideal model to practice public relations whatever the entity subject to study is; and even if the entity is not applying this ideal model, it will need to modify its practices for better execution of the communication function. Examples of these studies are countless (ex: Esfeler, 2011; 
Cannon, 2008; Moorlag, 2007; Chio, 2007; Grammer, 2005). The current study utilized the findings from the previous studies and many others to set the main procedures executed by the researchers regarding the practices of the excellence theory in Omani PR agencies.

\section{Major Findings}

The following part bears the presentation and discussion of the major findings of the current study divided into three aspects according to the study questions as follows:

The internal regulation framework for public relations agencies and firms in the Sultanate of Oman.

The following lines reveal the findings related to both: the PR practices in the agencies located in the Sultanate of Oman and the characteristics of excellence in the PR practice of agencies in light of the PR model executed in the internal managerial practices of the agency.

\section{Table (3)}

Specialization of the PR agencies/firms in Oman

\begin{tabular}{|c|c|c|c|}
\hline No & Specialization of the PR Agency/Firm & frequency & Ratio \\
\hline 1 & $\begin{array}{c}\text { The agency is specialized in the field of public relations } \\
\text { and advertising }\end{array}$ & 31 & $54.4 \%$ \\
\hline 2 & $\begin{array}{c}\text { The agency is specialized in one activity or certain } \\
\text { activities of public relations }\end{array}$ & 11 & $19.3 \%$ \\
\hline 3 & $\begin{array}{c}\text { The agency is specialized in all or most activities of } \\
\text { public relations }\end{array}$ & 8 & $14 \%$ \\
\hline 4 & $\begin{array}{c}\text { The agency is specialized in the field of public relations } \\
\text { and another field }\end{array}$ & 7 & $12.3 \%$ \\
\hline Total & 57 & $100 \%$ \\
\hline
\end{tabular}

The previous table reveals the misconception of PR in the agency work in Oman, that $54.4 \%$ percent of the sample is conducting both the work of PR and advertising, while $14 \%$ is conducting all or most PR activities; thus reflecting on the need to further clarify the PR concept and distinguish PR practices from advertising practices. 
Table (4)

Internal Departments of the PR agencies/firms in Oman

\begin{tabular}{|c|c|c|c|c|c|c|}
\hline & \multicolumn{2}{|c|}{ Practiced } & \multicolumn{2}{|c|}{ Not practiced } & \multicolumn{2}{|c|}{ Total } \\
\hline & Frequency & Ratio & Frequency & Ratio & Frequency & Ratio \\
\hline Coordination Dept. & 50 & $87.7 \%$ & 7 & $12.3 \%$ & 57 & $100 \%$ \\
\hline $\begin{array}{c}\text { Media Relations } \\
\text { (traditional media \& new } \\
\text { media) Dept. }\end{array}$ & 48 & $84.2 \%$ & 9 & $15.8 \%$ & 57 & $100 \%$ \\
\hline $\begin{array}{c}\text { Managing Relations in } \\
\text { Social Networking Sites } \\
\text { Dept. }\end{array}$ & 47 & $82.5 \%$ & 10 & $17.5 \%$ & 57 & $100 \%$ \\
\hline Writing Dept. & 40 & $70.2 \%$ & 17 & $29.8 \%$ & 57 & $100 \%$ \\
\hline $\begin{array}{l}\text { Publications production } \\
\text { Dept. }\end{array}$ & 33 & $57.9 \%$ & 24 & $42.1 \%$ & 57 & $100 \%$ \\
\hline $\begin{array}{l}\text { Production for the Web } \\
\text { Dept. }\end{array}$ & 32 & $56.1 \%$ & 25 & $43.9 \%$ & 57 & $100 \%$ \\
\hline $\begin{array}{l}\text { Purchase of Print } \\
\text { Materials Dept. }\end{array}$ & 30 & $52.6 \%$ & 27 & $47.4 \%$ & 57 & $100 \%$ \\
\hline $\begin{array}{c}\text { Audiovisual Production } \\
\text { Dept. }\end{array}$ & 29 & $50.9 \%$ & 28 & $49.1 \%$ & 57 & $100 \%$ \\
\hline $\begin{array}{c}\text { Research Management } \\
\text { Dept. }\end{array}$ & 21 & $36.8 \%$ & 36 & $63.2 \%$ & 57 & $100 \%$ \\
\hline Marketing Dept. & 5 & $8.8 \%$ & 52 & $91.2 \%$ & 57 & $100 \%$ \\
\hline Design Dept. & 2 & $3.5 \%$ & 55 & $96.5 \%$ & 57 & $100 \%$ \\
\hline Translation Dept. & 1 & $1.8 \%$ & 56 & $98.2 \%$ & 57 & $100 \%$ \\
\hline Accounting Dept. & 1 & $1.8 \%$ & 56 & $98.2 \%$ & 57 & $100 \%$ \\
\hline
\end{tabular}

As far as being legal managerial entities in themselves with employees and organizational charts, the internal organization of the departments in those firms in descending order are: coordination dept. between different departments of the agency resulting into an easier workflow, managing the agencies' media relations, managing social media accounts, writing, producing and purchasing publications and audiovisual material dept., conducting research, executing marketing plans, designing, translating and managing profit depts. respectively. 
Table (5)

Degree of practicing the four PR models in PR agencies/firms in Oman

\begin{tabular}{|c|c|c|c|c|c|c|c|c|}
\hline \multirow[t]{2}{*}{ The Statement } & \multicolumn{2}{|c|}{ Agree } & \multicolumn{2}{|c|}{ Neutră } & \multicolumn{2}{|c|}{ DIsagree } & \multicolumn{2}{|c|}{ Total } \\
\hline & $F$ & $R$ & $F$ & $\mathrm{R}$ & $F$ & $\mathrm{R}$ & $F$ & $\mathrm{R}$ \\
\hline $\begin{array}{l}\text { The methods of communication which are } \\
\text { used by the agency are characterized by } \\
\text { being comprehensive and accurate }\end{array}$ & 54 & $94.7 \%$ & 3 & $5.3 \%$ & 0 & $0 \%$ & 57 & $100 \%$ \\
\hline $\begin{array}{c}\text { The agency where I work is promoting itselt } \\
\text { to clients }\end{array}$ & 48 & $84.2 \%$ & 7 & $12.3 \%$ & 2 & $3.5 \%$ & 57 & $100 \%$ \\
\hline $\begin{array}{l}\text { The success of public relations at the agency } \\
\text { is measured by the number of clients who } \\
\text { attend an event the company promoted }\end{array}$ & 20 & $35.1 \%$ & 28 & $49.1 \%$ & 9 & $15.8 \%$ & 57 & $100 \%$ \\
\hline $\begin{array}{l}\text { Conducting research is an unnecessary } \\
\text { mission for any agency specialized in public } \\
\text { relations }\end{array}$ & 7 & $12.3 \%$ & 10 & $17.5 \%$ & 40 & $70.2 \%$ & 57 & $100 \%$ \\
\hline $\begin{array}{l}\text { The role of the agency is to transter a real } \\
\text { complete picture of itself to the client }\end{array}$ & 49 & $86 \%$ & 6 & $10.5 \%$ & 2 & $3.5 \%$ & 57 & $100 \%$ \\
\hline $\begin{array}{l}\text { Keeping files for what is published by the } \\
\text { media is the best way to determine the } \\
\text { success of communication programs } \\
\text { provided for clients }\end{array}$ & 27 & $47.4 \%$ & 26 & $45.6 \%$ & 4 & $7 \%$ & 57 & $100 \%$ \\
\hline $\begin{array}{l}\text { PublIc relations tends to conduct } \| t t t e \\
\text { research to study client's needs or attitudes }\end{array}$ & $\mathrm{TT}$ & $29.8 \%$ & 19 & $33.3 \%$ & 21 & $36.8 \%$ & 57 & $100 \%$ \\
\hline $\begin{array}{l}\text { Persuasion Is not the main goal of the } \\
\text { communication programs that are directed to } \\
\text { clients in the agency }\end{array}$ & 14 & $24.6 \%$ & 16 & $28.1 \%$ & 27 & $47.4 \%$ & 57 & $100 \%$ \\
\hline $\begin{array}{c}\text { The nature of communication in the agency } \\
\text { has two directions, from the agency to the } \\
\text { clients and vice versa in order to gain the } \\
\text { satisfaction of both parties }\end{array}$ & 55 & $96.5 \%$ & 2 & $3.5 \%$ & 0 & $0 \%$ & 57 & $100 \%$ \\
\hline $\begin{array}{l}\text { Public relations programs begin with } \\
\text { measuring clients attitudes to ensure that } \\
\text { they clarify the company policies in ways that } \\
\text { attract the clients }\end{array}$ & 45 & $78.9 \%$ & $\Pi 1$ & $19.3 \%$ & $T$ & $1.8 \%$ & 57 & $100 \%$ \\
\hline $\begin{array}{c}\text { The aim of the public relations in the agency } \\
\text { is to change the behaviors and attitudes of } \\
\text { the clients }\end{array}$ & 28 & $49.1 \%$ & 19 & $33.3 \%$ & 10 & $17.5 \%$ & 57 & $100 \%$ \\
\hline $\begin{array}{l}\text { The goal of the agency is to persuade the } \\
\text { clients to be committed to the agency rules } \\
\text { and policies }\end{array}$ & 21 & $36.8 \%$ & 29 & $50.9 \%$ & 7 & $12.3 \%$ & 57 & $100 \%$ \\
\hline $\begin{array}{l}\text { Betore the implementation of communication } \\
\text { programs directed to the clients, the agency } \\
\text { revises research conducted earlier in order to } \\
\text { identify the level of understanding between } \\
\text { the agency and the clients }\end{array}$ & 51 & $89.5 \%$ & 6 & $10.5 \%$ & 0 & $0 \%$ & 57 & $100 \%$ \\
\hline $\begin{array}{c}\text { Public relations act as a mediator between } \\
\text { the agency and the clients to overcome any } \\
\text { obstacles or problems that might restrain the } \\
\text { goals' fulfillment }\end{array}$ & 44 & $77.2 \%$ & 12 & $21.1 \%$ & 1 & $1.8 \%$ & 57 & $100 \%$ \\
\hline $\begin{array}{c}\text { Public relations mainly aim to achieve mutual } \\
\text { understanding between the agency and the } \\
\text { clients }\end{array}$ & 43 & $75.4 \%$ & 10 & $17.5 \%$ & 4 & $7 \%$ & 57 & $100 \%$ \\
\hline $\begin{array}{l}\text { Agency programs are based on the } \\
\text { agreement with the clients, taking into } \\
\text { consideration their reactions and } \\
\text { suggestions }\end{array}$ & 33 & $57.9 \%$ & 6 & $10.5 \%$ & 18 & $31.6 \%$ & 57 & $100 \%$ \\
\hline
\end{tabular}

Following Grunig four models of PR, the sample showed significant inclination towards practicing the two-way models either symmetrical or non-symmetrical. Some statements scored the highest agreement rates in the two-way models as "The nature of communication in the agency has two directions, from the agency to the clients and vice versa in order to gain the satisfaction of both parties" scoring an 
agreement rate of $96.5 \%$. Another such statement states "Before the implementation of communication programs directed to the clients, the agency revises research conducted earlier in order to identify the level of understanding between the agency and the clients" scoring an agreement rate of $89.5 \%$.

Prevalence of the two-way models is reasonable in PR agencies, since they are communication-based firms, so they are mostly eligible to practice the balanced models. To further elaborate on the most salient model in PR practice in PR agencies, the upcoming table depicts the salience of the models as follows:

Table (6)

Ranking of the four PR models in PR agencies/firms in Oman

\begin{tabular}{|c|c|c|c|}
\hline PR Model & Mean & Standard Deviation & Rank \\
\hline $\begin{array}{c}\text { The symmetrical } \\
\text { model }\end{array}$ & 10.60 & 1.116 & 2 \\
\hline $\begin{array}{c}\text { The asymmetrical } \\
\text { model }\end{array}$ & 10.30 & 1.362 & 3 \\
\hline Press Agentry & 9.37 & 1.345 & 4 \\
\hline Public Information & 8.93 & 1.450 & \\
\hline
\end{tabular}

Ranking of the four models according to the mean calculated from the summation of the sentences representing each model revealed the salience of the two-way symmetrical model in PR practice in Omani agencies with a mean of 10.6 followed shortly by the two-way asymmetrical model with a mean of 10.3 . This finding proves that PR Omani agencies practice the models related to the PR excellence. Press agentry and Public Information models followed respectively revealing the traditional practice of $\mathrm{PR}$.

The following series of tables tackle multiple aspects comprising the characteristics of excellence as suggested by Grunig. Those tables reflect the characteristics of $\mathrm{PR}$ excellence as practiced by $\mathrm{PR}$ Agencies in Oman. 


\section{Table (7)}

The characteristics of excellence in PR agencies/firms in Oman

\begin{tabular}{|c|c|c|c|c|c|c|c|c|}
\hline \multirow[t]{2}{*}{ The statement } & \multicolumn{2}{|c|}{ Agree } & \multicolumn{2}{|c|}{ Neutral } & \multicolumn{2}{|c|}{ Disagree } & \multicolumn{2}{|c|}{ Total } \\
\hline & $\mathrm{F}$ & $R$ & $\mathrm{~F}$ & $\mathrm{R}$ & $\mathrm{F}$ & $\mathrm{R}$ & $\mathrm{F}$ & $\mathrm{R}$ \\
\hline $\begin{array}{l}\text { Strategic Management in } \\
\text { Communication Programs } \\
\text { contributes in achieving better } \\
\text { results in communicating with } \\
\text { the public }\end{array}$ & 52 & $91.2 \%$ & 5 & $8.8 \%$ & 0 & $0 \%$ & 57 & $100 \%$ \\
\hline $\begin{array}{l}\text { Involving both males and } \\
\text { females in public relations in the } \\
\text { agency leads to a better } \\
\text { practice of public relations }\end{array}$ & 47 & $82.5 \%$ & 9 & $15.8 \%$ & 1 & $1.8 \%$ & 57 & $100 \%$ \\
\hline $\begin{array}{l}\text { The involvement of Public } \\
\text { Relations Practitioner in the } \\
\text { Strategic Management } \\
\text { processes of the agency is } \\
\text { important for a successful } \\
\text { management }\end{array}$ & 46 & $80.7 \%$ & 11 & $19.3 \%$ & 0 & $0 \%$ & 57 & $100 \%$ \\
\hline $\begin{array}{l}\text { Providing equal opportunities in } \\
\text { public relations roles for males } \\
\text { and females in the agency leads } \\
\text { to an excellent practice of public } \\
\text { relations }\end{array}$ & 46 & $80.7 \%$ & 11 & $19.3 \%$ & 0 & $0 \%$ & 57 & $100 \%$ \\
\hline $\begin{array}{l}\text { Public Relations should play an } \\
\text { integrated communications } \\
\text { function in the agency }\end{array}$ & 44 & $77.2 \%$ & 12 & $21.1 \%$ & 1 & $1.8 \%$ & 57 & $100 \%$ \\
\hline $\begin{array}{c}\text { Involving clients in decision } \\
\text { making at the agency contributes } \\
\text { to achieve better success for the } \\
\text { work }\end{array}$ & 36 & $63.2 \%$ & 15 & $26.3 \%$ & 6 & $10.5 \%$ & 57 & $100 \%$ \\
\hline $\begin{array}{c}\text { Public Relations Practitioner in } \\
\text { the agency should be a part of } \\
\text { the Higher Management of the } \\
\text { agency }\end{array}$ & 25 & $43.9 \%$ & 27 & $47.4 \%$ & 5 & $8.8 \%$ & 57 & $100 \%$ \\
\hline $\begin{array}{l}\text { Public Relations should be a } \\
\text { separated function from other } \\
\text { departments in the agency }\end{array}$ & 15 & $26.3 \%$ & 25 & $43.9 \%$ & 17 & $29.8 \%$ & 57 & $100 \%$ \\
\hline
\end{tabular}

The results from this table showed that the statement "Strategic Management in communication programs contributes in achieving better results in communicating with the public" ranked first with an approval rate of $91.2 \%$. On the other hand, the least approval rate (26.3\%) was scored by the statement "Public Relations should be separated function from other departments in the agency". 
These results reveal that public relations agencies in Oman believe in the importance of managing communication programs strategically, that is, they understand the importance of strategic analysis, strategic planning, implementation and strategic control over the success of communications programs. However, they do not realize the importance of separating the public relations profession as an independent department from other departments in the agency. This result may be contributed to the simplicity of the internal hierarchy of the agency, and lack of awareness of the importance of separation.

The study confirms clearly the application of agencies in the current study of the characteristics of excellence in the practice of public relations in terms of (enabling the function of public relations) and the violation of the characteristics of excellence in terms of (regulating the function of communication and its relationship to other administrative functions)

Table (8)

The participation of Public Relations Practitioner in the Strategic Management processes of the agency/firm

\begin{tabular}{|c|c|c|}
\hline $\begin{array}{c}\text { The participation of Public Relations Practitioner in the } \\
\text { Strategic Management processes }\end{array}$ & Frequency & Ratio \\
\hline Yes & 38 & $86.4 \%$ \\
\hline No & 6 & $13.6 \%$ \\
\hline Total & 44 & $100 \%$ \\
\hline
\end{tabular}

*Note: 44 agencies responded to this question only

Table (9)

The extent of participation of Public Relations Practitioners in the Strategic Management processes of the agency/firm

\begin{tabular}{|c|c|c|}
\hline $\begin{array}{c}\text { The extent of participation of Public Relations } \\
\text { Practitioner in the Strategic Management } \\
\text { processes }\end{array}$ & Frequency & Ratio \\
\hline Following up strategic plans & 29 & $76.3 \%$ \\
\hline Viewing strategic plans & 28 & $73.7 \%$ \\
\hline Implementing strategic plans & 28 & $73.7 \%$ \\
\hline Setting up strategic plans & 28 & $73.7 \%$ \\
\hline Evaluating strategic plans & 26 & $68.4 \%$ \\
\hline
\end{tabular}

*Note1: Agencies can choose more than one alternative

*Note2: 38 agencies only (who answered yes to the previous question) responded to this question 
The previous two tables tackled one of the most important excellence characteristics, which is the participation of the PR practitioners in the agency in the strategic management of the entity. Only 44 agencies out of the sample responded to this question. Of these 44 agencies only 38 with a rate of $86.4 \%$ allow their PR practitioners to participate in the strategic management process of the entity via different methods, scoring highest for following up the strategic plans and lowest for evaluating strategic plans.

The results reflect the involvement of public relations practitioners in public relations agencies in the Sultanate of Oman in all strategic management processes; from the development of plans, review, implementation, follow-up, and evaluation. The researchers predict that the public relations practitioner will be better involved in strategic management processes in the future. The ratios have shown good levels of participation at present. Nevertheless, as illustrated in table (10), senior management doesn't understands the need for the public relations to participate as part of the agency's board of directors which is considered a set back of the PR role.

Table (10)

The involvement of Public Relations Practitioner in the board of directors of the agency/firm

\begin{tabular}{|c|c|c|}
\hline $\begin{array}{c}\text { The involvement of Public Relations Practitioner in the } \\
\text { board of directors of the agency/company }\end{array}$ & Frequency & Ratio \\
\hline Yes & 20 & $45.45 \%$ \\
\hline No & 24 & $54.55 \%$ \\
\hline Total & 44 & $100 \%$ \\
\hline
\end{tabular}

The results of the table indicate lack of excellence of the public relations agencies involved in this regard. The researchers believe that this is due to the lack of awareness of senior management in agencies of the important role played by PR practitioners as a link between senior management and the client; especially if it has the freedom to defend the views and attitudes of clients before senior management; and clarify the policy and objectives of the agency to clients. 
Services provided by public relations agencies and firms in the Sultanate of Oman to clients.

The following part tackles the second aspect of the current study, i.e. services provided to clients by the study sample; and the excellence of the offered services to clients based on the excellence theory distinction between managerial and technical functions. Finally, the gender roles in practicing managerial versus technical oriented services is clarified, followed by the types of consultations offered to clients.

\section{Table (11)}

The extent to which the managerial versus technical oriented services are provided by the agencies/firms to clients in Oman

\begin{tabular}{|c|c|c|c|}
\hline Service & $\begin{array}{c}\text { Service orientation } \\
\text { (managerial /technical) }\end{array}$ & Frequency & Ratio \\
\hline Managing media relations & Managerial & 46 & $80.7 \%$ \\
\hline $\begin{array}{c}\text { Planning and evaluating media } \\
\text { campaigns }\end{array}$ & Managerial & 42 & $73.7 \%$ \\
\hline $\begin{array}{l}\text { Planning and evaluating advertising } \\
\text { campaigns }\end{array}$ & Managerial & 40 & $70.2 \%$ \\
\hline Strategic Planning & Managerial & 34 & $59.6 \%$ \\
\hline Managing Social Networks Accounts & Managerial & 29 & $50.9 \%$ \\
\hline $\begin{array}{l}\text { Conducting research and measuring } \\
\text { Public Opinion trends }\end{array}$ & Managerial & 27 & $47.4 \%$ \\
\hline Crisis Management & Managerial & 27 & $47.4 \%$ \\
\hline Negotiation \& Problem Solving & Managerial & 24 & $42.1 \%$ \\
\hline $\begin{array}{l}\text { Acting as Official Spokesperson on } \\
\text { behalf of institutions }\end{array}$ & Managerial & 20 & $35.1 \%$ \\
\hline \begin{tabular}{l|l} 
Issues Management \\
\end{tabular} & Managerial & 17 & $29.8 \%$ \\
\hline Designing logos & Technical & 46 & $80.7 \%$ \\
\hline Designing Posters \& Advertisements & Technical & 41 & $71.9 \%$ \\
\hline Producing Media Publications & Technical & 40 & $70.2 \%$ \\
\hline Writing for the media & Technical & 40 & $70.2 \%$ \\
\hline Organizing media events & Technical & 39 & $68.4 \%$ \\
\hline Organizing Meetings\& Seminars & Technical & 39 & $68.4 \%$ \\
\hline Organizing Press Conferences & Technical & 39 & $68.4 \%$ \\
\hline Organizing Exhibitions & Technical & 38 & $66.7 \%$ \\
\hline Producing Advertising Publications & Technical & 36 & $63.2 \%$ \\
\hline $\begin{array}{l}\text { Writing newsletters \& content of } \\
\text { and brochures booklets }\end{array}$ & Technical & 35 & $61.4 \%$ \\
\hline Designing \& editing online advertising & Technical & 34 & $59.6 \%$ \\
\hline Designing websites & Technical & 33 & $57.9 \%$ \\
\hline Editing Public Relations texts & Technical & 33 & $57.9 \%$ \\
\hline Preparing memos \& annual reports & Technical & 32 & $56.1 \%$ \\
\hline Producing audio-visual materials & Technical & 29 & $50.9 \%$ \\
\hline Outdoor Advertising & Technical & 27 & $47.4 \%$ \\
\hline Multimedia Design & Technical & 24 & $42.1 \%$ \\
\hline Producing audio materials & Technical & 21 & $36.8 \%$ \\
\hline
\end{tabular}


The distinction between managerial and technical services was identified by the study sample

The above table asserts that the managerial oriented service "Media Relations Management" and the technical oriented service "Design of logos and trademarks" took the lead as the most practiced services by the sample of the study, with a high rate of $80.7 \%$ each. The table also shows that the managerial service "planning and evaluation of media campaigns" ranked second by $73.7 \%$, followed by the technical service "design posters and advertisements" in third place by $71.9 \%$. Most of the other services in the table scored high ratios, demonstrating the ability of public relations agencies in Oman to practice most of the modern public relations services. In total, the sample practices 10 managerial oriented services versus 18 technical oriented services, proving the prevalence of the technical oriented services as a major practice. Nevertheless, the results reflected a positive image residing in the interest of the study sample in the managerial services, scoring some of the highest ratios.

These results explain that public relations agencies in Oman have approached public relations excellence, in terms of their interest in the managerial oriented services and in terms of the ability of the public relations practitioners to perform well in both types of services.

Choosing a random assortment of services, agencies were asked to specify whether the service in their entity is offered by a male employee, female, or both. The results are demonstrated hereafter. 
Table (12)

Distribution of service performance according to gender in the agencies/firms in Oman

\begin{tabular}{|c|c|c|c|c|c|c|c|c|c|c|}
\hline & \multirow{2}{*}{$\begin{array}{l}\text { The type of } \\
\text { service } \\
\text { (manageria } \\
\text { । } \\
\text {-technical) }\end{array}$} & \multicolumn{6}{|c|}{ Gender } & \multicolumn{2}{|c|}{$\begin{array}{c}\text { Not } \\
\text { applicable }\end{array}$} & \multirow[t]{2}{*}{$\begin{array}{c}\text { Tota } \\
\text { I }\end{array}$} \\
\hline & & M & $\begin{array}{l}\mathrm{R} \\
\%\end{array}$ & $\mathrm{~F}$ & $\begin{array}{l}\mathrm{R} \\
\%\end{array}$ & $\begin{array}{c}\text { male } \\
\& \\
\text { femal } \\
e\end{array}$ & $\begin{array}{l}\mathrm{R} \\
\%\end{array}$ & $\mathrm{~F}$ & $\begin{array}{l}\mathrm{R} \\
\%\end{array}$ & \\
\hline $\begin{array}{l}\text { Managing } \\
\text { media } \\
\text { relations }\end{array}$ & Managerial & $\begin{array}{l}1 \\
6\end{array}$ & $\begin{array}{c}28 . \\
1\end{array}$ & $\begin{array}{l}2 \\
1\end{array}$ & $\begin{array}{c}36 . \\
8\end{array}$ & 18 & $\begin{array}{c}31 . \\
6\end{array}$ & 2 & 3.5 & 57 \\
\hline $\begin{array}{l}\text { Negotiation \& } \\
\text { Problem } \\
\text { Solving }\end{array}$ & Managerial & $\begin{array}{l}2 \\
6\end{array}$ & $\begin{array}{c}45 . \\
6\end{array}$ & 4 & 7 & 15 & $\begin{array}{c}26 . \\
3\end{array}$ & $\begin{array}{l}1 \\
2\end{array}$ & $\begin{array}{c}21 . \\
1\end{array}$ & 57 \\
\hline $\begin{array}{c}\text { Planning } \\
\text { Communicatio } \\
\text { n programs }\end{array}$ & Managerial & $\begin{array}{l}1 \\
8\end{array}$ & $\begin{array}{c}31 . \\
6\end{array}$ & $\begin{array}{l}1 \\
1\end{array}$ & $\begin{array}{c}19 . \\
3\end{array}$ & 15 & $\begin{array}{c}26 . \\
3\end{array}$ & $\begin{array}{l}1 \\
3\end{array}$ & $\begin{array}{c}22 . \\
8\end{array}$ & 57 \\
\hline $\begin{array}{c}\text { Designing } \\
\text { websites }\end{array}$ & Managerial & $\begin{array}{l}1 \\
8\end{array}$ & $\begin{array}{c}31 . \\
6\end{array}$ & 5 & 8.8 & 12 & $\begin{array}{c}21 . \\
1\end{array}$ & $\begin{array}{l}2 \\
2\end{array}$ & $\begin{array}{c}38 . \\
6\end{array}$ & 57 \\
\hline $\begin{array}{l}\text { Writing for the } \\
\text { media }\end{array}$ & Technical & $\begin{array}{l}1 \\
8\end{array}$ & $\begin{array}{c}31 . \\
6\end{array}$ & $\begin{array}{l}1 \\
6\end{array}$ & $\begin{array}{c}28 . \\
1\end{array}$ & 13 & $\begin{array}{c}22 . \\
8\end{array}$ & $\begin{array}{l}1 \\
0\end{array}$ & $\begin{array}{c}17 . \\
5\end{array}$ & 57 \\
\hline $\begin{array}{c}\text { Designing } \\
\text { logos and } \\
\text { advertisement } \\
\text { s }\end{array}$ & Technical & $\begin{array}{l}3 \\
0\end{array}$ & $\begin{array}{c}52 . \\
6\end{array}$ & 5 & 8.8 & 13 & $\begin{array}{c}22 . \\
8\end{array}$ & 9 & $\begin{array}{c}15 . \\
8\end{array}$ & 57 \\
\hline $\begin{array}{l}\text { Producing } \\
\text { Publications }\end{array}$ & Technical & $\begin{array}{l}2 \\
6\end{array}$ & $\begin{array}{c}45 . \\
6\end{array}$ & 4 & 7 & 14 & $\begin{array}{c}24 . \\
6\end{array}$ & $\begin{array}{l}1 \\
3\end{array}$ & $\begin{array}{c}22 . \\
8\end{array}$ & 57 \\
\hline $\begin{array}{l}\text { Organizing } \\
\text { Meetings, } \\
\text { Seminars \& } \\
\text { conferences }\end{array}$ & Technical & $\begin{array}{l}1 \\
2\end{array}$ & $\begin{array}{c}21 . \\
1\end{array}$ & $\begin{array}{l}1 \\
4\end{array}$ & $\begin{array}{c}24 . \\
6\end{array}$ & 23 & $\begin{array}{c}40 . \\
4\end{array}$ & 8 & 14 & 57 \\
\hline $\begin{array}{c}\text { Producing } \\
\text { audio-video } \\
\text { materials }\end{array}$ & Technical & $\begin{array}{l}2 \\
2\end{array}$ & $\begin{array}{c}38 . \\
6\end{array}$ & 4 & 7 & 13 & $\begin{array}{c}22 . \\
8\end{array}$ & $\begin{array}{l}1 \\
8\end{array}$ & $\begin{array}{c}31 . \\
6\end{array}$ & 57 \\
\hline
\end{tabular}

The results above specify that the most common service performed by males is the technical service "design"; which accounted for $52.6 \%$ of the total number of the study sample; while the most common service performed by women is the managerial service "managing media relations" which accounted for $36.8 \%$ of the total number of the study sample. "Organizing meetings, seminars and conferences" is the technical service mostly performed by both males and females accounting for $40.4 \%$. These results are consistent with the hypothesis 
of the excellence theory, that stated clearly that women are the most appropriate to provide the managerial (communication) oriented services in PR; although the result percentages in the current study is still not enough.

The role of women needs to be further activated, because in most services, women are outnumbered. This is due, of course, to the small number of women working in Omani agencies. In terms of managerial oriented services, men outnumber women except for "managing media relations" service. The results of the current study thus violate the hypotheses of the excellence theory in public relations in terms of supporting women working in the public relations sector.

The results further clarify that there is diversity in the roles of both men and women working in Omani agencies, nevertheless, there is no equality in opportunities between men and women in the practice of managerial services, and it is clear through the results that men dominate women in most management activities.

Table (13)

Consultations provided by the agency/firm for clients

\begin{tabular}{|c|c|c|}
\hline Consultation & Frequency & Ratio \\
\hline Marketing consultations & 53 & $93 \%$ \\
\hline Media Consultations & 44 & $77.2 \%$ \\
\hline Management Consultations & 23 & $40.4 \%$ \\
\hline Corporate Strategy Consultations & 13 & $22.8 \%$ \\
\hline Legal Consultations & 1 & $1.8 \%$ \\
\hline
\end{tabular}

The previous results assert that $93 \%$ of Omani agencies provide "Marketing Consultations" for clients; followed by "Media Consultations" with a high percentage of $77.2 \%$, while "Management Consultations" reached an average of $40.4 \%$. The last two ranks were scored by "Corporate strategic consultations" with $22.8 \%$ only and "legal consultations" with a rate of $1.8 \%$.

These results were justified by the fact that more than half the sample are agencies specialized in both PR and advertising, that is why 
marketing consultations dominate the consultations provided herein. On the other hand, media consultations ranking second is also justified, by the fact that the institutions seek to strengthen their relations with the various media through these agencies; which supports the above mentioned result in Table No. 12 of the managerial service " Managing media relations" scoring the highest proportion by $80.7 \%$

Creativity practices executed by $P R$ agencies and firms in the Sultanate of Oman to provide a better clientele experience

The upcoming part bears the answer to the question on creative practices executed by Omani agencies, through answering two openended questions on the most creative practices executed by the study sample from their own point of view and their opinion on creativity practiced in Omani PR agencies.

\section{Table (14)}

Creative activities as perceived by PR Omani agencieslfirms

\begin{tabular}{|c|c|c|}
\hline Creative activity & Frequency & Ratio \\
\hline Organizing Conferences & 47 & 82.5 \\
\hline Advertising \& Promotion & 46 & 80.7 \\
\hline Provide Media \& Marketing Consultations & 45 & 78.9 \\
\hline Organizing Activities \& Events & 43 & 75.4 \\
\hline Media Relations & 40 & 70.2 \\
\hline Printing \& Production services & 38 & 66.7 \\
\hline Preparing Strategic Plans & 37 & 64.9 \\
\hline Organizing Exhibitions & 35 & 61.4 \\
\hline Digital Services & 32 & 56.1 \\
\hline Building Corporate Identity & 28 & 49.1 \\
\hline Reputation Management & 26 & 45.6 \\
\hline $\begin{array}{c}\text { Providing Training in the field of Public Relations \& } \\
\text { Media }\end{array}$ & 22 & 38.6 \\
\hline Radio \& Television Production & 19 & 33.3 \\
\hline Social Responsibility & 18 & 31.6 \\
\hline $\begin{array}{c}\text { Doing research to identify the attitudes and behaviors } \\
\text { of public opinion }\end{array}$ & 15 & 26.3 \\
\hline Crisis Management \& Negotiation & 14 & 24.6 \\
\hline International Relations and etiquette and Protocol \\
Ceremonies & 5 & 8.8 \\
\hline Graphic Design & 3 & \\
\hline Cinema production & 2 & 3.3 \\
\hline Photography & 1 & 1.8 \\
\hline
\end{tabular}


The results of the above table clarify that organizing conferences is perceived by Omani agencies as the most creative activity they perform with a rate of $82.5 \%$. This result is logic taking into account that organizing conferences is one of the most prominent activities performed by most agencies in Oman. Advertising and promotion's creativity come second at a rate of $80.7 \%$ since more than half of the study sample is specialized in the field of public relations and advertising. These two results reflect the importance of creativity in communication in public relations. Preparing strategic plans is considered a creative activity by $64.9 \%$ of the study sample, proving that creativity can also be executed at a strategic level, not only on execution

levels. It is clear that the services related to "photography," "production," and "graphic design" scored the lowest creativity rate although these are highly creative activities. The reason for this dilemma resides in the answers to the open question to agency executives on creativity concept and the point of view and opinions on creativity practiced in Omani PR agencies.

The study sample highlighted the creativity of public relations in PR agencies in Oman as being under-rated. Some executives revealed that: "traditional methods drift away from the scientific dimensions of creativity and tend to focus on being productive, in the least budget possible, given the fierce competition in the communication market nowadays". Others asserted that: "non-creative ideas prevail in different PR contents especially in such activities as writing press releases and event management, while the outside look and format of the production are sometimes inclined towards luxury and creativity more".

The researchers could explain these findings in light of the novelty of the PR practice in Oman as a whole, and that includes the practice of PR agencies. Most agencies are local, adopting the trial and error method of serving their clients, thus being exposed to lack of 
creativity problems. In order to keep enhancing creativity in PR practice in Oman, some agencies suggest:

- Depending on more qualified personnel to do creative work either locals or expats.

- Simplifying the procedures of merging SME agencies to be able to acquire big client accounts with more funding; thus surpassing the budget limit problems.

- Encouraging clients to take creative risks through thorough explanation of all the creative procedures from the strategic formulation downwards.

- Excluding imitation of previously successful PR projects and seeking innovation in all matters related to public relations.

\section{Answering Research Questions, Discussion and Recommendations}

The current research is set to answer one major question from which three sub-questions are derived as follows:

A) Questions concerning the internal regulation framework for public relations agencies and firms in the Sultanate of Oman.

1) What is the description of $P R$ practices in the agencies located in the Sultanate of Oman?

The study results reveal the misconception of PR practices in the agency work in Oman, that $54.4 \%$ percent of the sample is conducting both the work of PR and advertising. Inside the agency, the coordination dept. is the most prominent department resulting into an easier workflow.

2) What are the characteristics of excellence in the PR practice of agencies in the Sultanate of Oman?

- One of the most important characteristics of excellence is the salience of the two-way symmetrical model in PR practice in Omani agencies. 
- The sample subject to study abides by the characteristics of excellence in the practice of public relations in terms of enabling the function of public relations strategically.

- There seems to be an involvement of public relations practitioners in public relations agencies in the Sultanate of Oman in all strategic management processes; from the development of plans, review, implementation, follow-up, and evaluation.

B) Questions related to the services provided by public relations agencies and firms in the Sultanate of Oman to clients.

1) What are the services and consultations offered by Omani PR agencies and firms to their clients?

- The study found out that the services "Media Relations Management" and "Design of logos and trademarks" took the lead as the most practiced services by the sample of the study followed by "planning and evaluation of media campaigns" and "design posters and advertisements".

- Most of the PR services performed scored high ratios, demonstrating the ability of public relations agencies in Oman to practice most of the modern public relations services.

- $93 \%$ of Omani agencies provide "Marketing Consultations" for clients; followed by "Media Consultations", "Management Consultations", "Corporate strategic consultations" and "legal consultations" respectively.

2) To what extent do public relations agencies and firms in the Sultanate of Oman apply the characteristics of excellence in providing their services to clients according to the two-way models governing the profession?

- Results reflect excellence in terms of residing to the managerial services, scoring some of the highest ratios. 
- Public relations agencies in Oman have approached public relations excellence, in terms of their interest in the managerial oriented services and in terms of the ability of the public relations practitioners to perform well in both types of services.

- The results clarify that there is diversity in the roles of both men and women working in Omani agencies, nevertheless, there is no equality in opportunities between men and women in the practice of managerial services, and it is clear through the results that men dominate women in most management activities as a step far from excellence.

C) What are the creativity practices executed by $P R$ agencies and firms in the Sultanate of Oman to provide a better clientele experience?

- Organizing conferences is perceived by Omani agencies as the most creative activity they perform followed by advertising and promotion's creativity.

- Preparing strategic plans is considered a creative activity by about two third of the study sample, proving that creativity can also be executed at a strategic level.

- The study sample highlighted the creativity of public relations in PR agencies in Oman as being under-rated and stated some recommendations to enhance creativity procedures.

In general, the results show that the public relations agencies in the Sultanate of Oman as managerial units abide by the actual reality of the excellent practices of the public relations profession to some extent; as they follow the characteristics of the Excellence Theory of Public Relations in some aspects, and fail to implement them in others. For instance, Public relations agencies in the Sultanate of Oman empower the public relations function; in terms of managing communication programs strategically, and in terms of involving 
public relations practitioners in the strategic management. Nevertheless, they don't empower the public relations function in terms of involving the public relations practitioners in the formation of the board of directors of the agencies subject to this study.

The study also complies with the characteristics of the Excellence Theory of Public Relation in terms of providing diversity of managerial and technical oriented services of public relations, and in terms of enabling men and women to practice the two types. On the other hand, the results don't comply with the characteristics of the theory in terms of providing equal opportunities for men and women to provide the managerial oriented services. Finally, results highlight the creativity of public relations in PR agencies in Oman as being under-rated. Traditional methods drift away from the productive divergence definition and tend to focus on being productive, in the least budget possible. Non-creative ideas prevail in different PR contents and ideas while the outside look of the production is inclined towards luxury and creativity more.

The study concludes that the two way symmetrical model is the most used model by the public relations agencies and companies in the Sultanate of Oman, as it is considered the best model in public relations practice according to the characteristics of the Excellence Theory of Public Relations.

Recommendations are based mainly on:

- Maintaining a balanced two-way model in the practice of public relations in public relations agencies in Oman, taking into account the continuous implementation of innovative communication programs with clients.

- Reconsidering the regulation of the communication function and its relationship to other administrative functions by separating public relations as an independent unit.

- Restructuring the organizational charts of public relations 
agencies to allow the public relations practitioners to participate in the Board of Directors, not only to participate in the strategic management processes, in order to act as a mediator between senior management in the organization and clients.

- Supporting women in public relations agencies through increasing the number of female employees, and allowing them to exercise managerial and communication orientation services.

- Depending on more qualified personnel to do creative work either locals or expats.

- Simplifying the procedures of merging SME agencies to be able to acquire big client accounts with more funding; thus surpassing the budget limit problems.

- Encouraging clients to take creative risks through thorough explanation of all the creative procedures from the strategic formulation downwards.

- Excluding imitation of previously successful PR projects and seeking innovation in all matters related to public relations. 


\section{References}

- $\quad$ Agwa, A. and Youssef, M. (2005), Planning and Management and Public Relations (in Arabic), Open University, Cairo University Print House, Cairo, Egypt.

- Al Hinai, T. (2012), "Public Relations in the Institutions of civil service in the Sultanate of Oman (Organizational, functional and communicational features: Survey Study", (in Arabic), Unpublished MA Thesis, Sultan Qaboos University, Muscat, Oman.

- Al Siyabi, M. (2015), "The Practice of Public Relations in Institutions of Higher Education "Department of Public Relations and Information At Sultan Qaboos University: A Case Study", (in Arabic), Unpublished M.A. Thesis, Sultan Qaboos University, Muscat, Oman.

- Bashir, M. \& Fedorova, M. (2014), "Conglomeration among the top American public relations agencies: A case study", Public Relations Review, Vol. 40, pp762-771.

- Botan, C. H. and Hazleton, V.C. (2009), Public Relations Theory. $2^{\text {nd }}$ ed., Routledge, New York.

- Cannon, D. F. (2008), Speaking of faith: "Public relations practice among Relations communicators In The United States", Unpublished Dissertation, The University of Texas, Austin USA.

- Chio, J. (2007), "Elaborating the concept of public relations roles and a test of its utility", Unpublished Dissertation, Michigan State University, USA.

- Daymon, C. (2000), "Cultivating creativity in public relations consultancies: The management and organization of creative work", Journal of Communication Management, Vol. 5 No. 1, pp. 17-30

- Deatherage, C. P. \& Hazleton, V. (2009), "Effects of Organizational Worldviews on the Practice of Public Relations: A Test of the Theory of Public Relations Excellence", Journal of Public Relations Research, Vol. 10 No. 1, pp. 57-71.

- Esfeller, IV, J. H. (2011), "Communications management in athletics and the Excellence Theory: A case study of The University Of South Alabama Football Program", Unpublished MA Thesis, The University of Alabama, USA.

- Everling, K. B. (2009), "Investigating the true return on investment: A descriptive Analysis of public relations agency-client relationships using the relqual scale", Unpublished Dissertation, Michigan State University, USA.

- Fedorova, M. (2012), "The economic analysis of public relations: American and Russian industries comparison": Unpublished MA Thesis, Indiana University", USA.

- Gallicano, T. D. (2013), "Relationship management with the millennial generation of public relations agency employees", Public Relations Review, Vol. 39, pp. 222-225.

- Ghazali, A. (2006), "Factors Affecting Public Relations Practice in Libyan Companies ", (in Arabic), Unpublished Ph.D. Dissertation, Cairo University, Cairo, Egypt.

- Gomez, J. G. (2007), "What Do We Know About Creativity?", The Journal of Effective Teaching, Vol. 7, pp 31-43.

- Grammer, E.M. (2005), "An exploration of the generic principles of Public Relations Excellence in Australia, Italy, Mauritius, And Uganda", Unpublished MA Thesis, University of Maryland, USA. 
- $\quad$ Green, A. (2010), Creativity in Public Relations. 4th ed, Kogan Page, London.

- Grunig, J. and Grunig, L. (1992), "Models of Public Relations and Communication", in Grunig J. (Ed.) Excellence in Public Relations and Communication Management, Lawrence Erlbaum Associates Inc., New Jersey.

- Grunig, J. and Hunt, T. (1984), Managing Public Relations, Holt, Rinehart and Winston, New York.

- Grunig, J. et al. (2008), Excellence in Public Relations and Communication Management, Routledge, New York.

- Hussein, F. (2009), "Roles and Models of Public Relations in Yemen", (in Arabic), Unpublished Ph.D. Dissertation, Cairo University, Cairo, Egypt.

- $\quad$ Ikram, F. (April 2015), "Perceptions of Public Relations Students in Oman: Examining the Perception of Public Relations Students to Their Education in Oman", Asian Journal of Management Sciences and Education, Vol. 4 No. 2, pp. 132-145

- Ismail, S. (2017), A Brief History of The Sultanate of Oman: Past and Present, (in Arabic), Gulf Journalism and Publishing, Muscat.

- Jakus, D. and Croatia, M. (2013), "Creative Communication in Public Relations Activities", Minib, No 10 (4), December 2013, pp. 1-10.

- Janus, J. M. (2008), "Gender roles leadership and public relations", Unpublished MA Thesis, University of Missouri - Columbia.

- $\quad$ Lages, C. and Simkin, L. (2003), " The dynamics of public relations: Key constructs and the drive for professionalism at the practitioner, consultancy and industry levels", European Journal of Marketing, Vol. 37 No. 1/2, pp. 298-328.

- Lim, S. et al. (2005), " Applicability of the Generic Principles of Excellent Public Relations in a Different Cultural Context: The Case Study of Singapore", Journal of Public Relations Research, Vol. 17 No. 10, pp. 315-340.

- $\quad$ Mart, L. \& Jackson, N. (2005), Public Relations agencies in the UK travel industry: Does size matter?, PRism 3, pp. 1-14.

- Molleda, J. C. et al. (2015), "Tipping the balance: A decision-making model for localization in global public relations agencies", Public Relations Review, Vol. 41, pp 335-344.

- Moorlag, L.M.J. (2007), "The U.S. Coast Guard Public Affairs Officers: Roles, perceptions, and culture- A communication Excellence Study", Unpublished MA Thesis, University of North Carolina, USA.

- Palea, A. (2010), "Creativity in Public Relations", Professional Communication and Translation Studies, Vol. 3 No. (1-2), pp 19-24.

- Remund, D. L. (2011), "Agency experience: A case study of leadership development within a high performing public relations agency", Unpublished Dissertation, University of North Carolina, USA.

- Sefertzi, E. (2000), Creativity, Report Produced for the EC Funded Project INNOREGIO: Dissemination of Innovation and Knowledge Management Techniques, January 2000.

- Taha, R. (2003), "The effect of Organizational Environment on the Communication 
Behavior of Organizations: An Analytical Field Study", (in Arabic), Unpublished MA Thesis, Cairo University, Cairo, Egypt.

- Traintafillidou, A. \& Yonnas, P. (2014), "How public relations agencies in Greece Respond to digital trends", Public Relations Review, Vol. 40, pp. 815-817.

- White, J. (2000), "Innovation, research and development in professional service firms: A comparison of management and public relations consultancies, drawing implications for public relations practice", Journal of Communication Management, Vol. 5 No. 1, pp. 8288.

- Wynee, R. (2013), "What does a public relations agency do?", Forbes, April 10, available at: https://www.forbes.com/sites/robertwynne/2013/04/10/what-does-a-publicrelations-agency-do/\#45b4403675d9 (accessed 5 May 2017).

- Youssef, M. and Zahra, I. (2011), "Public Relations Research: Current Reality and Futuristic Trends", (in Arabic), in Half a Century of Communication Research in Egypt: Current and Future Trends, 17th International Conference of Cairo University, Faculty of Mass Communication in collaboration with UNESCO, 19-20 December, pp. 123-165.

- Zahra, I. (2002), "Public Relations in the Multinational Corporations Operating in Egypt: A Survey Study", (in Arabic), Unpublished MA Thesis, Cairo University, Cairo, Egypt.

- Zahra, I. (2014), "Rebranding Egypt as a Sustainable Tourist Destination after the Uprisings", paper presented at VII International Tourism Congress entitled: The Image and Sustainability of Tourist Destinations, Muscat, Oman, 2-4 December 2014.

- Zahra, I. (2015), "Public Relations Research in the Arab World: Historical Overview and Futuristic Perspectives with a Special Focus on PR Research Status in The Sultanate of Oman", paper presented at AUSACE $20^{\text {th }}$ Annual Conference entitled: Global Trends and Prospects in Mass Communication, Doha, Qatar, 24-26 October 2015.

- Zerfass, A. et al. (2008), Public Relations Research: European and International Perspectives and Innovations, VS Verlag Fur Sozialwisse- nschaften, Wiesbaden. 